\title{
Pulau Hilang: Wilayah Teritorial Berkurang?
}

\author{
Deramadana Ersya*; Novianti \\ Fakultas Hukum Universitas Jambi \\ *Coresponding author: deraersya@unja.ac.id \\ Submission : 14 Juli 2020 \\ Revision : 31 Oktober 2020 \\ Publication : 20 November 2020 \\ DOI : doi.org/10.36565/up.v1i2.9936
}

\begin{abstract}
Global warming becomes as an inevitable issue. This phenomenon has an impact on all aspects of life. One of the impacts is the rise in sea level which can cause the sinking of an island. The study discussed the effect that global warming will have on national borders at the UNCLOS 1982 and that new international policies will be needed to deal with the effects of global warming on country areas. This type of research was normatif yuridis, which sourced in secondary data. By taking several approaches, the approach of legislation (approach approach) and the case approach (case approach). Based on the study, the 1982 sea law convention asa rule in imposing maritime limits has not been able to answer the question of the sea's level rise and impact on the region's capital.
\end{abstract}

Keywords: Baseline; Global Warming; Rising Sea Levels; Territorial Territory

\begin{abstract}
Abstrak
Pemanasan global menjadi isu yang tidak dapat dihindarkan.Fenomena ini berdampak pada semua aspek kehidupan.Salah satu dampaknya adalah kenaikan permukaan air laut yang dapat mengakibatkan tenggelamnya suatu pulau.Penelitian ini membahas dampak pemanasan global terhadap batas laut wilayah negara menurut konvensi hukum laut 1982 serta diperlukan kebijakan internasional yang baru untuk menghadapi pengaruh pemanasan global terhadap wilayah negara.Jenis Penelitian ini adalah yuridis normatif, yang bersumber pada data
\end{abstract}


sekunder.Pendekatan yang digunakan adalah pendekatan perundang-undangan (Statute Approach) dan pendekatan kasus (Case Approach). Berdasarkan penelitian ditemukan bahwa Konvensi Hukum Laut 1982 yang menjadi acuan dalam menetapkan batas maritime belum dapat menjawab persoalan terkait kenaikan permukaan air laut dan dampaknya terhadap wilayah territorial

\section{Kata Kunci: Garis Pangkal; Pemanasan Global; Kenaikan Permukaan Air Laut; Wilayah Teritorial}

\section{A. Pendahuluan}

Sejak satu abad terakhir bumi yang didiami lebih dari tujuh miliar orang sedang dihadapkan pada sebuah fenomena yang disebut pemanasan global. Fenomena ini disebabkan oleh efek gas rumah kaca yang dihasilkan dari proses alamiah dan aktivitas manusia. Sebagian besar emisi gas rumah kaca terdiri dari gas $\mathrm{CO}_{2}$. Efek gas rumah kaca banyak digunakan di negara 4 musim untuk pertanian.Panas matahari ditangkap dengan rumah-rumah kaca yang dibuat oleh para penduduk.Efek memerangkap inilah yang kemudian disebut efek rumah kaca.

Gas rumah kaca inilah yang menyebabkan suhu permukaan bumi terus mengalami peningkatan. Diagram dibawah ini menunjukkan bahwa sejak era 1980-an kenaikan temperature bumi semakin tinggi.Era ini adalah saat

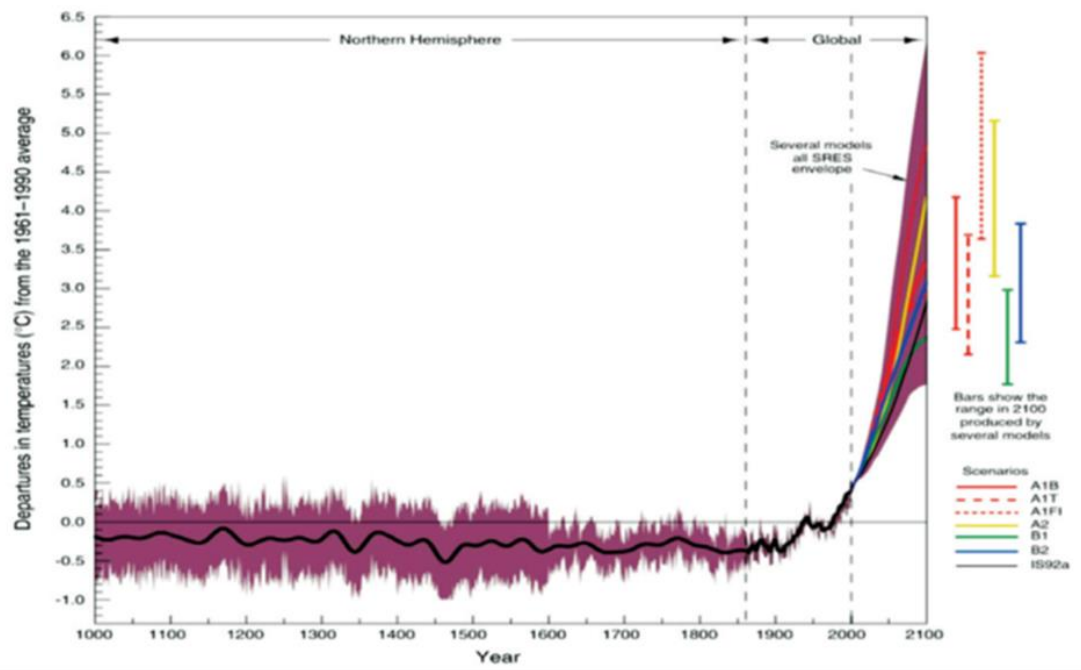


Revolusi industri pertama terjadi pada abad ke-18 ditandai dengan penemuan mesin uap yang digunakan untuk proses produksi barang. Pada masa ini bahan bakar fosil mulai digunakan secara masif dan akhirnya menghasilkan gas rumah kaca yang terus meningkat di atmosfer bumi.

Atmosfer yang menghangat juga diikuti dengan menghangatnya lapisan permukaan laut. Hal ini akan menyebabkan membersarnya volume dan meningkatnya tinggi permukaan air laut. Selama abad ke-20 tercatat bahwa peningkatan tinggi muka laut di seluruh dunia mencapai 10 $25 \mathrm{~cm}$ (4 - 10 inchi).Prediksi yang dikemukakan oleh ilmuwan IPCC mengenai peningkatan lebih lanjut pada abad ke-21 dapat mencapai 9 - $88 \mathrm{~cm}$ (4 - 35 inchi). ${ }^{2}$

Kenaikan permukaan air laut diprediksi akan menenggelamkan $6 \%$ daerah Belanda, 17,5\% daerah Bangladesh, dan kurang lebih 2000 pulau kecil di Indonesia akan tenggelam (IPCC 2007). Negara-negara dengan pertumbuhan ekonomi yang tinggi tidak akan mengeluarkananggaran yang besaruntuk mempertahankan wilayahlautnya,sedangkan negara-negara dengan kondisi ekonomi yang masih rendah mungkin hanya dapat melakukanevakuasi dari daerah pantai. ${ }^{3}$

Jepang misalnya, dalam tiga tahun terakhir, sejumlah pulau nya menghilang dari permukaan laut akibat pemanasan global. Dalam menghadapi tantangan iklim, saat ini Jepang sedang membetoni sebuah atol bernama Okinotorishima, $1.740 \mathrm{~km}$ di selatan Tokyo yang akan menghabiskan dana lebih

2 Sulistyono."Pemanasan Global (Global Warming) dan Hubungannya dengan Penggunaan Bahan Bakar Fosil”.Forum Teknologi.Vol 2 No. 2.Hal 52.

3 Ibid..Hal 53

Uti Possidetis: Journal of International Law, Vol. 1, No. 2 (2020) 
dari \$100 juta. ${ }^{4}$ Dengan luas 10 meter persegi karang tersbut itu hanya tampak setinggi 16 sentimeter ketika laut pasang. Keberadaan karang dimaksud sebagai akses terhadap ZEE seluas $400.000 \mathrm{~km}$ per segi untuk dieksploitasi oleh Jepang. ${ }^{5}$

Menghilangnya suatu pulau kecil terluar sebagai titik pangkal akan berdampak pada hilangnya tanda fisik penentu suatu wilayah. Hilangnya sebagian pulau terluar akan berbuntut timbulnya masalah-masalah baru terkait wilayah laut suatu negara, dan akan berdampak pentin terhadap keutuhan kedaulatan. ${ }^{6}$

Adanya wilayah territorial yang jelas merupakan salah satu ciri Negara dengan kedaulatan penuh. ${ }^{7}$ Menurut Oppenheim, suatu Negara tidak bias diakui sebagai subjek HI tanpa adanya wilayah dengan batas-batas tertentu. Untuk menandakan terdapatnya kekuasaan tertinggi dan eksklusif Negara, wilayah menjadi sesuatu yang penting dalam hukum internasional. ${ }^{8}$

Langkah yang dilakukan Jepang adalah mempertahankan klaim teritorialnya atas pulau terluar yang berada di wilayah perbatasan. Namun klaim Jepang tersebut menuai kecaman dari beberapa negara, karena dalam Konvensi Hukum Laut dicantumkan bahwa batuan atau karang yang tidak bisa menopang kehidupan manusia atau ekonomi secara mandiri tidak memiliki zona ekonomi ekslusif.

4 https://time.com/4205570/okinotorishima-japan-maritime-claims/.

Diakses pada 20 Agustus 2020

5 https://news.detik.com/dw/d-5043441/jepang-pertaruhkan-

kedaulatan-selamatkan-pulau-kecil-dari-kenaikan-air-laut. diakses pada 20 Agustus 2020

6 Harkins Hendro Prabowo. "Potensi Tenggelamnya Pulau-Pulau Kecil Terluar Wilayah NKRI". Jurnal Geologi Kelautan.Vol 14 No 2. November 2016. Hal 116.

7 Vera W S Soemarwi, 'Kedaulatan Udara Indonesia dan UpayaUpaya Perlindungannya', Era Hukum No 1, 2016, hal. 209

8 Mochtar Kusumaatmadja dan Etty R.Agoes, Pengantar Hukum Internasional, cet. 5, PT. Alumni, Bandung, 2015, hal 170 
Pengaturan secara menyeluruh terkait kedaulatan dan yurisdiksi negara di laut mulai dilakukan oleh empat Konvensi-konvensi Jenewa tahun 1958.Seiring berkembangnya teknologi penambangan di dasar laut dan bertambahnya jumlah negara baru yang baru merdeka, muncul tuntutan-tuntutan baru terhadap laut, dan konvensi tersebut dianggap tidak lagi memadai. Dengan perundingan yang cukup lama, keputusannya disepakati Konvensi Hukum Laut 1982 yang terdiri dari 320 pasal dan 9 Annex. ${ }^{9}$

Dalam konvensi ini diatur semua aspek kegiatan yang dilakukan di laut, termasuk mengenai penentuan garis pangkal. Namun pemanasan global menimbulkan tantangan dan tuntutan baru dalam hukum internasional yang telah ada, yaitu, bagaimana dampak pemanasan global terhadap batas laut wilayah negara menurut konvensi hukum laut 1982 serta diperlukan kebijakan internasional yang baru untuk menghadapi pengaruh pemanasan global terhadap wilayah negara.

\section{B. Metode Penelitian}

Tipe penelitian yang digunakan adalah metode penelitian yuridis normatif (normative legal research). Menurut Soerjono Soekanto dan Sri Mamudji penelitian normatif adalah penelitian yang hanya meneliti bahan pustaka atau data sekunder. Penelitian ini menerapkan beberapa pendekatan, yaitu pendekatan perundang-undangan (Statute Approach)dan pendekatan kasus (Case Approach). ${ }^{10}$

\section{Pembahasan dan Analisis}

$9 \quad$ Ibid.. hal 171

10 Tentang pendekatan ini, lihat Peter Mahmud Marzuki.Penelitian Hukum. Jakarta: Prenadamedia Grup. 2005. hal. 133. 
Pembahasan dan analisis dalam artikel bertujuan untuk menjawab rumusan masalah dan pertanyaan-pertanyaan penelitian, menunjukkan bagaimana temuan-temuan itu diperoleh, menerangkan arti hasil penelitian, bagaimana hasil penelitian dapat memecahkan masalah serta kemungkinan pengembangannya. Pembahasan dan analisis harus menjawab permasalahan dan tujuan penelitian.

\section{Dampak Pemanasan Global Terhadap Garis Pangkal}

Pemanasan global diartikan sebagai naiknya suhu bumi secara menyeluruh.Berdasarkan laporan IPCC, sepanjang 3 abad belakangan, pada umumnya telah meningkat 1 derajat Celcius di permukaan bumi. Kenaikan temperatur tersebut mengancam kehidupan di bumi. Menurut kesimpulan IPCC bahwa peningkatan suhu rata-rata global terjadi dimulai pada pertengahan abad ke-20.Meningkatnya gas rumah kaca sebagai dampak kegiatan manusia melalui ERK.

Gas rumah kaca adalah selimut bahan gas berupa udara, yakni bahan udara di sekeliling bumi (yang merupakan bagian tak terpisahkan dengan biosfer dan eksofer yang dapat menunjang kehidupan). ${ }^{11}$ Gas rumah kaca dalam jumlah yang wajar sangat penting bagi kehidupan di muka bumi, sebab tanpa itu suhu bumi menjadi terlalu dingin sehingga tidak dapat dihuni. Tetapi apabila gas rumah kaca seperti uap air, karbon dioksida, metana dan lainnya semakin banyak di atmosfer bumi, maka energi matahari berupa cahaya yang berubah menjadi panas ketika sampai ke permukaan bumi akan terperangkap di atmosfer bumi. Keadaan demikianlah yang menyebabkan suhu permukaan bumi terus meningkat.

Salah satu dampak utama dari perubahan iklim sejauh ini adalah mencairnya es. Secara umum, jika es mencair maka

A.M. Yunus Wahid, Pengantar Hukum Lingkungan, Prenadamedia Grup, Jakarta, 2018, hal. 58 
permukaan air laut akan meningkat. Pencairan es yang terjadi di wilayah Kutub Utara dan Antartika, juga lapisan es dan gletser yang mencair di seluruh Greenland, Eropa dan wilayah lainnya, diprediksi dapat meningkatkan kenaikan permukaan laut secara signifikan. ${ }^{12}$

Akibat perubahan iklim dan naiknya permukaan laut, banyak negara pesisir dan pulau yang rentan bisa menderita dampak fisik, ekonomi, dan budaya yang parah.Dampak tersebut mungkin diperburuk oleh hilangnya wilayah karena pergeseran batas laut.13jika suatu wilayah negara tenggelam, maka tidak akan ada lagi daratan, dan tidak akan menghasilkan zona maritim. ${ }^{14}$

Kenaikan permukaan laut terutama disebabkan oleh dua faktor yang berkaitan dengan pemanasan global: penambahan air dari lapisan es dan gletser yang mencair dan perluasan air laut saat memanas. Grafik pertama mengukur perubahan permukaan laut sejak 1993 seperti yang diamati oleh satelit.Grafik kedua, yang berasal dari data pengukur pasang surut pantai, menunjukkan seberapa besar permukaan laut berubah dari sekitar tahun 1870 hingga 2013.15

12 https://www.livescience.com/37057-global-warming-effects.h tml. Diakses pada 8 Juli 2020

13 Ann Powers, Sea-Level Rise and Its Impact on Vulnerable States: Four Examples, 73 La. L. Rev. 151 (2012)

14 Stuart Kaye, "The Law of the Sea Convention and Sea Level Rise after the South China Sea Arbitration". International Law Study. Vol 93(2017). Hal 429

15 https://climate.nasa.gov/vital-signs/sea-level/. Diakses pada 7 Juli 2020.

Uti Possidetis: Journal of International Law, Vol. 1, No. 2 (2020) 


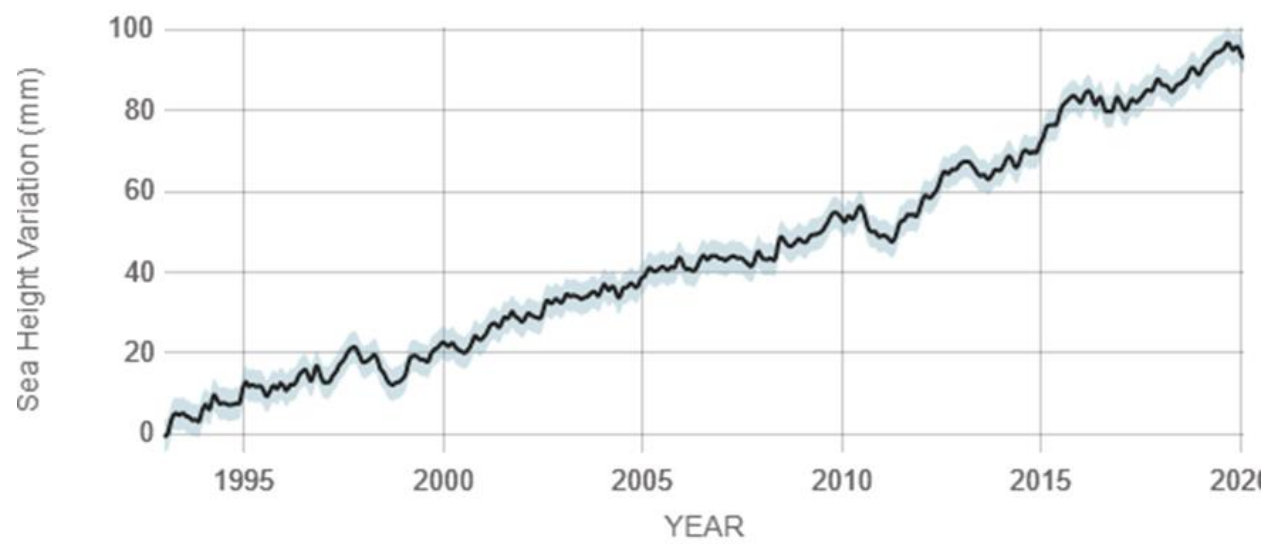

Source: climate.nasa.gov

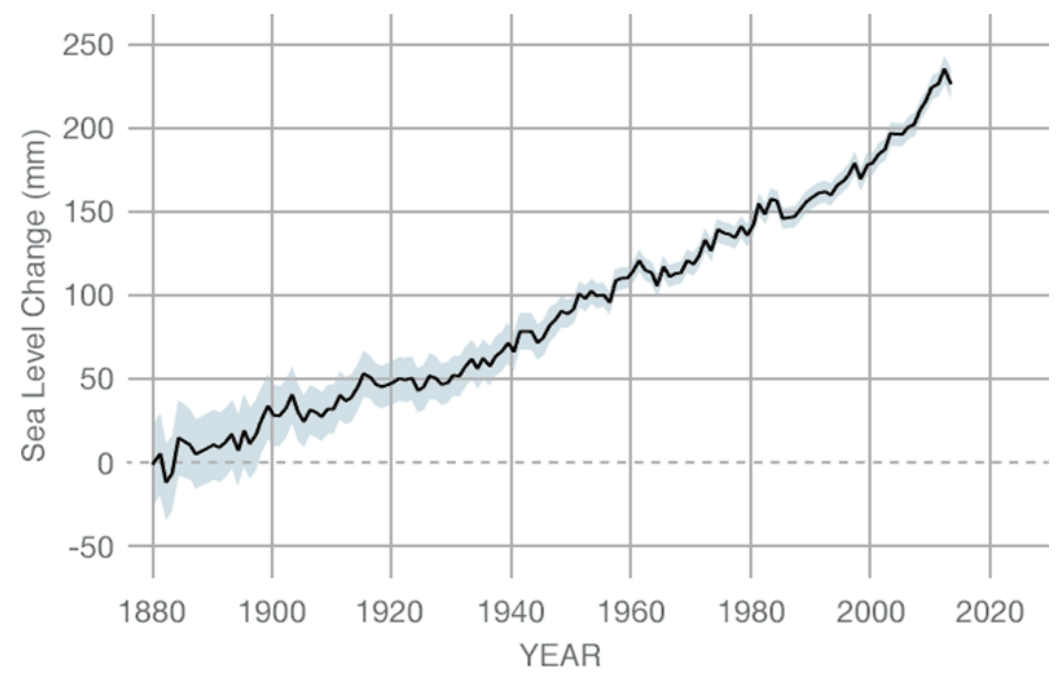

Saat ini telah banyak pulau di beberapa negara yang kehilangan sebagian daratannya bahkan nyaris tenggelam seluruhnya.Tuvalu, negara kepulauan yang terletak antara Hawaii dan Australia menjadi salah satu negara yang yang paling rentan di dunia terhadap kenaikan permukaan laut, dengan ketinggian rata-rata hanya satu meter di atas permukaan laut. Efek kenaikan permukaan laut, kemungkinan 
besar akan mengakibatkan hilangnya lahan secara signifikan dan berpotensi mengurangi ZEE-nya.

Dengan lebih dari 80\% luas daratannya kurang dari satu meter di atas laut tingkat dan ketinggian tertinggi tidak lebih dari tiga meter, Maladewa adalah negara lain yang paling rentan terhadap kenaikan permukaan laut. Republik Kiribati yang terletak di Samudra Pasifik juga masuk dalam daftar negara yang terancam tenggelam, daratan Kiribati hanya berada 2 meter dari permukaan laut pada titik tertingginya. Ilmuwan memprediksikan bahwa 32 pulau di Kiribati akan tenggelam sepenuhnya dalam 50 tahun kedepan. ${ }^{16}$

Kenaikan permukaan air laut juga berdampak pada Jepang. Beberapa tahun terakhir, sebagian pulau menghilang dari permukaan laut, seperti Esanbe Hanakita Kojima yang baru dinamakan pada 2014, tetapi pada awal 2018 tidak lagi muncul di permukaan. Suzume Kitakojima juga menjadi salah satu pulau yang kini sudah menghilang.Pulau ini tercantum pada peta buatan tahun 1985 .

Kehilangan sebagian pulau tidak memudarkan keinginan Jepang untuk tetap mempertahankan wilayahnya. Membetoni Atol Okinotorishima menjadi salah satu cara, karena keberadaannya menjadi penting untuk dapat mengakses ZEE seluas $400.000 \mathrm{~km} 2$ agar dapat dieksploitasi oleh Jepang.

Pergesaran pada garis pantai menyebabkan berubahnya luas wilayah perairan laut suatu daerah serta batas fisik wilayah negara dengan negara lain menjadi tidak jelas. Sehingga untuk menyatakan potensi kekayaan sumber daya kelautan juga harus disertai dengan penentuan batas wilayah laut.Wilayah perbatasan suatu negara di laut dapat berupa batas laut teritorial, batas landas kontinen, maupun batas zona ekonomi eksklusif.Batas-batas tersebut digunakan sebagai

16 https://www.idntimes.com/news/world/resty/5-negara-yang-terancam -tenggelam-bukti-nyata-pemanasan-global-c1c2/3. Diakses pada 7 Juli 2020

Uti Possidetis: Journal of International Law, Vol. 1, No. 2 (2020) 
pagar-pagar yuridis serta politis berlakunya kedaulatan dan yurisdiksi nasional.

\section{Penetapan Batas Laut dalam United Nations Convention on The Law of the Sea (UNCLOS)}

Status kenegaraan merupakan hal pokok mengingat Negara sebagai aktor penting dalam hukum internasional. Penguasaan suatu wilayah territorial menjadi salah satu factor dari unsur status kenegaraan. Pada wilayah ini kekuasaan paling tinggi dimiliki oleh negara yang bersangkutan. ${ }^{17}$ Pembagian wilayah territorial terdiri dari wilayah darat, laut dan udara. Penentuan batas dengan Negara tetangga perlu diperjelas pada tiga wilayah territorial ini.

United Nations Convention on The Law of the Sea (UNCLOS) atau yang sering disebut Konvensi Hukum Laut PBB 1982 merupakan sumber pokok dalam hukum internasional untuk mengukur batas-batas laut. Konvensi ini berisi ketentuan-ketentuan yang mengatur berbagai zona martim dengan status hukum yang berbeda-beda. Secara umum, dalam Konvensi ini terdapat dua bagian zona maritime, diantaranya yang pertama zona-zona maritime yang berada di bawah yurisdiksi nasional yang dibagi menjadi zona maritime dibawah kedaulatan penuh Negara pantai diantaranya perairan pedalaman, perairan kepulauan dan laur teritorial serta zona maritime di mana Negara pantai bisa menjalankan kewenangannya serta beberapa hak khusus yang tunduk pada aturan dalam konvensi, yang termasuk zona maritime ini adalah jalur tambahan, zona ekonmi ekslusif, dan landas kontinen. Pembagian zona maritime yang kedua adalah zona maritime di luar yurisdiksi nasional, diantaranya laut lepas dan kawasan dasar laut internasional. ${ }^{18}$

17 J.G.Starke. Pengantar hukum internasional.Cetakan ke- 13. Sinar Grafika. Jakarta. 2016. Hal 210

18 Etty R. Agoes. "Pengaturan Tentang Wilayah Perairan Indonesia dan Kaitannya dengan Konvensi Hukum Laut 1982".Makalah yang 
UNCLOS 1982 mengatur hampir segala aspek kegiatan di laut, termasuk mengenai penentuan garis pangkal, yaitu garis darimana batas terluar laut teritorial dan zona maritim lain negara pantai. Berdasarkan ketentuan UNCLOS 1982 terdapat tiga jenis garis pangkal, yaitu :

a. Garis Pangkal Biasa (Normal Baseline)

Dalam Pasal 5 UNCLOS 1982 disebutkan bahwa garis pangkal biasa untuk mengukur lebar laut territorial adalah garis air rendah sepanjang pantai sebagaimana yang ditandai pada peta skala besar yang secara resmi diakui oleh Negara pantai tersebut. Negara pantai mempunyai kedaulatan atas Laut Teritorial, ruang udara diatasnya, dasar laut dan tanah di bawahnya serta kekayaan alam yang terkandung didalamnya, dimana dalam pelaksanaannya kedaulatan atas laut teritorial ini tundukpada ketentuan hukum internasional. ${ }^{19}$ Penentuan batas terhadap wilayah suatu negara merupakan tuntutan satu pihak yang tunduk kepada aturan dalam hukum internasional.

Pasal 6 UNCLOS 1982 menyebutkan bahwa, dalam hal pulau yang terletak pada atoll atau pulau yang mempunyai karang-karang di sekitarnya, maka garis pangkal yang untuk mengukur lebar laut territorial adalah garis air rendah pada sisi karang ke arah laut sebagaimana ditunjukkan oleh tanda yang jelas untuk itu pada peta yang diakui resmi oleh Negara pantai yang bersangkutan.

Dalam penentuan garis pangkal tidak hanya ditentukan dengan klaim sepihak negara pantai. The Anglo-Norwegian Fisheries Case (1951) menentukan bahwa Batasan wilayah laut selalu merupakan aspek internasional; ia tidak dapat bergantung hanya pada kemauan negara pantai seperti yang

disampaikan pada ceramah Fakultas Hukum Universitas Trisakti.Jakarta. 16-19 Januari 1996. Hal 2

${ }^{19}$ Akbar Kurnia Putra. Hak Lintas Damai (Right of Innocent Passage) Berdasarkan United Nation Convention on The Law of The Sea 1982. Jurnal Ilmu Hukum, Volume 7, Nomor 2. 2016. Hal 27. 
dinyatakan dalam hukumnya. Oleh sebab itu, penetapan garis pangkal suatu negara haruslah sesuai dengan ketentuan yang terdapat pada UNCLOS 1982 sebagai sumber pokok dalam hukum laut internasional. ${ }^{20}$

b. Garis Pangkal Lurus (Straight Baseline)

Bentuk kontur pantai setiap negara yang tidak seragam membuat garis pangkal biasa tidak bisa diterapkan secara universal. Pasal 7 UNCLOS 1982 berisi aturan mengenai cara penarikan garis pangkal lurus dari ujung ke ujung (straight baseline) sebagai cara yang bisa ditetapkan dalam kondisikondisi khusus. ${ }^{21}$

Garis pangkal lurus dapat diterapkan pada tempat-tempat dimana garis pantai menjorok jauh ke dalam dan menikung ke dalam atau jika ada suatu jajaran pulau sepanjang pantai di dekatnya, dan dalam hal delta serta keadaan alam lainnya terdapat ketidakstabilan garis pantai, sehingga negara pantai dapat, dalam kondisi tertentu, menggunakan garis pangkal lurus untuk menentukan dari mana luas laut teritorial diukur. (Paramita Volume 2, Nomor 1, Januari 2019)

Ada beberapa ketentuan dalam pasal 7 yang harus diperhatikan dalam menggunakan penarikan garis pangkal lurus, diantaranya yaitu, pertama, tidak dapat keluar terlampau jauh dari arah umum dari pada pantai dan bagian laut yang berada pada garis pangkal demikian tidak boleh jauh dengan daratan agar tunduk pada rezim perairan dalam.

Kedua, tidak dapat ditarik ke dan dari elevasi surut kecuali jika diatasnya didirikan mercusuar atau instalasi serupa yang secara permanen ada di atas permukaan laut atau kecuali dalam hal penarikan garis pangkal lurus ke dan dari elevasi demikian telah memperoleh pengakuan umum

20 Arie Afriansyah, 'Kewenangan Negara Pantai Dalam Mengelola Wilayah Laut', Jurnal Hukum \& Pembangunan, 45.4 (2015), 607 <https://doi.org/10.21143/jhp.vol45.no4.63>.

21 Dikdik Mohammad Sodik. Op.Cit. Hal 23 
internasional. Adapun yang dimaksud dengan elevasi surut adalah suatu wilayah daratan yang ketika air surut berada di atas permukaan laut, dan ketika pasang berada di bawah permukaan laut.

Ketiga, dalam menetapkan garis pangkal lurus demikian dapat diperhatikan kebutuhan-kebutuhan istimewa yang bersifat ekonomis dari suatu daerah yang dapat dibuktikan oleh kebiasaan-kebiasaan dan kebutuhan yang telah berlangsung lama. Keempat, tidak bisa digunakan jika cara penarikan yang demikian memotong laut territorial Negara lain dari laut lepas atau ZEE.

c. Garis Pangkal Kepulauan (Archipelagic Baseline)

Garis pangkal ini hanya digunakan oleh negara yang memenuhi kriteria sebagai negara kepulauan. Pasal 47 UNCLOS mengatur syarat dan aturan yang harus dipenuhi suatu negara dalam menarik garis pangkal kepulauan, yaitu :

1. Perbandingan antara luas wilayah daratan dan lautan adalah satu banding satu atau sembilan banding satu;

2. Panjang garis pangkal tidak boleh melebihi 100 mil laut, kecuali jika tiga persen dari jumlah semua garis pangkal yang ada disekeliling setiap kepulauan lebih dari 100 mil, maka bisa digunakan batas maksimum 125 mil laut.

3. Penarikan garis pangkal demikian tidak boleh menyimpang terlalu jauh dari konfigurasi umum kepulauan tersebut.

4. Garis pangkal demikian tidak boleh ditarik ke dan dari elavasi surut, kecuali apabila diatasnya telah dibangun mercu suar atau instalasi serupa yang secara permanen berada di atas permukaan laut atau apabila elevasi surut tersebut terletak seluruhnya atau sebagian pada suatu jarak yang tidak melebihi lebar laut territorial dari pulau yang terdekat.

5. Sistem garis pangkal demikian tidak boleh diterapkan oleh suatu negara kepulauan dengan cara yang demikian 
rupa sehingga memotong laut territorial Negara lain dari laut lepas atau zona ekonomi ekslusif

6. Apabila suatu bagian perairan kepulauan suatu Negara kepulauan terletak diantara dua bagian suatu negara tetangga yang langsung berdampingan, hak-hak yang ada dan kepentingan-kepentingan yang sah lainnya dilaksanakan secara tradisional oleh Negara tersebut terakhir di perairan demikian serta segala hak yang ditetapkan dalam perjanjian antara negara-negara tersebut akan tetap berlaku dan harus dihormati.

7. Untuk perbandingan perairan dalam dengan daratan berdasarkan ketentuan ayat 1 , daerah daratan dapat mencakup di dalamnya perairan yang terletak di dalam tebaran karang, pulau-pulau dan atol, termasuk bagian plateau oceanic yang bertebing curam yang tertutup atau hamper tertutup oleh serangkaian pulau batu gamping dan karang kering di atas permukaan laut yang terletak disekeliling plateau tersebut.

8. Garis pangkal yang ditarik berdasarkan ketentuan pasal ini, harus dicantumkan pada peta dengan skala atau skala-skala yang memadai untuk menegaskan posisinya. Sebagai gantinya, dapat dibuat daftar koordinat geografis titik-titik yang secara jelas memerinci datum geodetik.

9. Negara kepulauan harus mengumumkan sebagaimana mestinya peta atau daftar koordinat geografis demikian dan harus mendepositkan satu salinan setiap peta atau daftar demikian pada Sekretariat Jenderal Perserikatan Bangsa-Bangsa.

Konvensi Hukum Laut 1982 yang mengatur garis pangkal tidak memberikan regulasi mengenai perubahan garis pangkal ataupun pergeseran garis pesisir pantai. Tetapi hanya mengatur mengenai bagaimana mengukur dan menentukan garis pangkal tergantung pada kondisi alamiah masing-masing negara pantai. Pasal 7 UNCLOS menyatakan bahwa 
'dikarenakan adanya delta dan keadaan alam lain, terjadi ketidakstabilan garis pantai', yang berarti bahwa UNCLOS 1982 benar-benar mengakui bahwa garis pantai pada garis pangkal lurus dapat berubah karena permukaan air laut.

Apabila terdapat suatu perubahan terutama mengenai kondisi naiknya permukaan air laut atau dampaknya pada negara, maka ketentuan tersebut tidak diatur dalam ruang lingkup UNCLOS 1982.22 Ketentuan yang terdapat dalam UNCLOS 1982 tidak dapat merespon secara efektif terhadap pergeseran-pergeseran yang terjadi pada garis pesisir pantai, yang juga akan berpengaruh pada penentuan garis pangkal laut untuk menentukan dimulainya laut teritorial suatu negara.

Meskipun Negara-negara pantai memiliki hak untuk menentukan garis pangkal untuk menentukan titik dimana pengukuran laut teritorial dimulai, serta berbagai zona lainnya yang didasarkan pada UNCLOS 1982, namun jika garis pangkal laut pada nyatanya mengalami perubahan dan dapat mengurangi luasnya laut teritorial suatu negara pantai, maka hal ini dapat menjadi permasalahan hukum internasional yang baru.

Kedaulatan territorial suatu negara tetap merupakan suatu konsep penting dalam hukum internasional. Perolehan dan hilangnya wilayah negara akan menimbulkan dampak hukum terhadap kedaulatan negara dan penduduk yang tinggal di wilayah tersebut. ${ }^{23}$

22 Hendra Yosep Siburian and Afrizal Tanjung, 'Pengaruh Perubahan Garis Pantai Terhadap Implementasi Hukum Laut Di Kecamatan Rangsang Barat Kabupaten Kepulauan Meranti The Effect of Changes in The Shoreline of The Sea Law Implementation in West Rangsang Subdistrict , Kepulauan Meranti District', 25.1 (2020), 5363.

23 Mochtar Kusumaatmadja dan Etty R.Agoes, Pengantar Hukum Internasional, cet. 5, PT. Alumni, Bandung, 2015, hal 162 


\section{Kebijakan Internasional dalam Menghadapi Dampak Pemanasan Global}

Dampak dari pemanasan global yang terkait dengan perubahan iklim seluruh dunia menjadi sesuatu yang dikhawatirkan, didorong perlu adanya peran serta dunia internasional dalam mengendalikan dan mengurangi efek GRK atau "greenhouse gases" (GHGs). ${ }^{24}$ Pemanasan global merupakan isu yang telah menjadi pembicaraan internasional serta menjadi salah satu poin penting Konferensi Tingkat Tinggi (KTT) Bumi Tahun 1992 di Rio de Janeiro. ${ }^{25}$ Konferensi tersebut menghasilkan United Nations Framework Convention on Climate Change (UNFCCC) atau Konvensi tentang Perubahan Iklim.

Conference of Party (COP) UNFCCC ketiga yang dilaksanakan di Kyoto, Jepang tahun 1997 dan menghasilkan Protokol Kyoto. Protokol tersebut menetapkan sejumlah target mengikat bagi negara-negara maju untuk memangkas emisi gas rumah kaca rata-rata lima persen dari tingkat tahun 1990.26Ketika berlaku pada tahun 2005, ada 141 negara meratifikasi Protokol Kyoto.Tetapi Amerika Serikat tidak ikut meratifikasi Protokol Kyoto.Kehadiran Protokol Kyoto tidak mendapat hasil yang memadai. ${ }^{27}$ Salah satu penyebabnya

24 Otto Soemarwoto, Indonesia Dalam Kancah Isu Lingkungan Global, PT Gramedia Pustaka Utama, Jakarta, 1992, h. 140. Geral Foley, Pemanasan Global,Siapakah Yang Merasakan Panas?, Yayasan Obor Indonesia, Konphalindo, Panos, Jakarta, 1993, h. 1

25 Suparto Wijoyo, 'INTERNATIONAL DINAMIC COMMITMENT IN THE CONTEXT OF GLOBAL WARMING Oleh: Suparto Wijoyo', 56, 2012, 13-35

26 https://www.voaindonesia.com/a/protokol-kyoto-akan-segera-kadalur warsa-tanpa-kepastian-akan-ada-penggantinya/1552087.html.

Diakses pada 5 Juli 2020

27 Deni Bram, 'Perspektif Keadilan Iklim Dalam Instrumen Hukum Lingkungan Internasional Tentang Perubahan Iklim', Jurnal 
karena, kurangnya peran serta Amerika Serikat sebagai negara yang berperan besar dalam peningkatan emisi $\mathrm{CO}_{2}$.

Selanjutnya pelaksanaan KTT Perubahan Iklim pada tahun 2009 menghasilkan Kesepakatan Kopenhagen (Copenhagen Accord). Kesepakatan ini salah satunya menetapkan pembatasan peningkatan suhu global dua derajat celsius dibanding tingkat pra industri pada 2050.28 Namun kesepakatan ini tidak mempunyai kekuatan mengikat, karena hanya sebuah rekomendasi atau himbauan yang ditujukan untuk negara-negara industri agar mendaftarkan target penurunan emisi dan negara-negara berkembang agar mendaftarkan strategi untuk mencegah polusi pemanasan global dalam jumlah tertentu.

Conference of Party (COP) 21 menghasilkan Paris Agreement atau Kesepakatan Paris.Kesepakatan ini menjadi suatu keberhasilan diplomasi perubahan iklim global.Paris Agreement merupakan kabar baik bagi perundingan terkait perubahan iklim setelah COP 15 di Copenhagen yang diadakan pada tahun 2009 gagal mencapai kesepakatan mengenai iklim global.Prinsip yang diadopsi Kesepakatan Paris adalah prinsip applicable to all Parties (berlaku untuk seluruh Pihak), memberikan tugas yang cukup besar kepada negara berkembang.

Dalam konvensi ini Negara berkembang disebut sebagai negara non-Annex, yang wajib berperan dalam upaya global untuk mengurangi emisi gas rumah kaca (GRK) dan di waktu yang sama juga harus ikut serta dalam menghadapi dampak dari perubahan iklim. ${ }^{29} \mathrm{Di}$ antara kesepakatan internasional

Dinamika

Hukum, 11.2

(2011)

<https://doi.org/10.20884/1.jdh.2011.11.2.187>

28 https://internasional.kompas.com/read/2010/02/01/03250389/Mema hami.Hasil.dari.Kopenhagen?page=all. Diakses pada 5 Juli 2020

29 http://iesr.or.id/indonesia-dan-ratifikasi-paris-agreement-di-m anakah-kita/. Diakses pada 5 Juli 2020

Uti Possidetis: Journal of International Law, Vol. 1, No. 2 (2020) 
yang telah ada hanya membahas bagaimana emisi gas rumah kaca dapat dikurangi, dan tidak ada satupun aturan yang secara jelas mengatur bagaimana penentuan garis pangkal jika terjadi perubahan akibat kenaikan permukaan air laut yang merupakan salah satu dampak dari pemanasan global.

Pemanasan global bukanlah isu yang dapat diabaikan.Saat ini instrumen hukum internasional yang ada hanya berisi aturan untuk mengurangi emisi gas rumah kaca, sehingga masih perlu diadakan pembaharuan kebijakan dalam bentuk kerangka hukum yang spesifik terutama dalam mempertahankan wilayah negara dari dampak pemanasan global.

\section{Penutup}

Tenggelamnya suatu pulau akan mempengaruhi wilayah territorial dari negara yang bersangkutan. Wilayah negara menjadi sesuatu yang sangat penting dalam hukum internasional.Konvensi Hukum laut internasional yang menjadi landasan dalam mengukur garis pangkal hanya mengatur mengenai tiga jenis garis pangkal, yaitu garis pangkal biasa (normal baseline), garis pangkal lurus (straight baseline), dan garis pangkal kepulauan (archipelagic baseline).Konvensi hukum internasional yang ada juga tidak memberikan jawaban mengenai penyelesaian akibat dampak yang ditimbulkan dari pemanasan global terhadap wilayah territorial suatu negara.Dengan demikian sangat penting adanya instrumen hukum yang baru untuk mengatasi persoalan ini.

\section{Referensi}

\section{Instrumen Hukum}

Republik Indonesia. Undang-Undang Nomor 32 Tahun 2014 Tentang Kelautan 
Keputusan Presiden Nomor 6 Tahun 2017 Tentang Penetapan Pulau-Pulau Kecil Terluar Kyoto Protocol 1997

Paris Agreement 2016

United Nations Convention on the Law of the Sea 1982

\section{Buku}

Kusumaatmaja, Mochtar dan Etty R. Agoes.Pengantar Hukum Internasional.Cetakan ke-5.P.T. Alumni, Bandung. 2015.

Marzuki, Peter Mahmud. Penelitian Hukum. Prenadamedia.Jakarta, 2005.

Sodik, Dikdik Mohammad. Hukum Laut Internasional, Refika Aditama. Bandung, 2016.

Starke, J.G. Pengantar hukum internasional.Cetakan ke- 13. Sinar Grafika. Jakarta. 2016

Wahid, A.M. Yunus. Pengantar Hukum Lingkungan. Cetakan ke1. Prenadamedia Group, Jakarta. 2018.

\section{Artikel/Jurnal}

Afriansyah, Arie. "Kewenangan Negara Pantai Dalam Mengelola Wilayah Laut", Jurnal Hukum \& Pembangunan, 45.4, 2015.

Bram, Deni. "Perspektif Keadilan Iklim Dalam Instrumen Hukum Lingkungan Internasional Tentang Perubahan Iklim"', Jurnal Dinamika Hukum, 11.2, 2011.

Kaye, Stuart. "The Law of the Sea Convention and Sea Level Rise after the South China Sea Arbitration".International Law Study.Vol 93. 2017.

Powers, Ann. "Sea-Level Rise and Its Impact on Vulnerable States: Four Examples”. 73 La. L. Rev. 151. 2012. 
Prabowo, Harkins Hendro and Muhammad Salahudin."Potensi Tenggelamnya Pulau-Pulau Kecil Terluar Wilayah Nkri”, Jurnal Geologi Kelautan, 14.2 2017.

Siburian, Hendra Yosep and Afrizal Tanjung.'Pengaruh Perubahan Garis Pantai Terhadap Implementasi Hukum Laut Di Kecamatan Rangsang Barat Kabupaten Kepulauan Meranti", JURNAL PERIKANAN DAN KELAUTAN Volume 25 No. 1, 2020.

Soemarwi, Vera W S. "Kedaulatan Udara Indonesia dan UpayaUpaya Perlindungannya”, Era Hukum No 1, 2016.

Wijoyo, Suparto. "Dinamika Komitmen Internasional Dalam Kerangka Pengendalian Global Warming", Kanun Jurnal Ilmu Hukum No. 56, Th. XIV, 2012.

\section{Laman}

Live Science, Effects of Global Warming. https://www.livescience.com/37057-global-warmingeffects.html. Diakses Pada 8 Juli 2020

Global

$$
\text { Climate }
$$

Change.Sea

Level.

https://climate.nasa.gov/vital-signs/sea-level/.

Diakses pada 7 Juli 2020

BBC News, Tiny Pacific nation takes on Australia. http://news.bbc.co.uk/2/hi/asia-pacific/1854118.stm. Diakses pada 7 Juli 2020

Idn Times, 5 Negara yang Terancam Tenggelam, Bukti Nyata Pemanasan Global. https://www.idntimes.com/news/world/resty/5negara-yang-terancam-tenggelam-bukti-nyatapemanasan-global-c1c2/3 Diakses pada 7 Juli 2020

VOA, Protokol Kyoto akan Segera Kadaluwarsa Tanpa Kepastian akan Penggantinya. https://www.voaindonesia.com/a/protokol-kyotoakan-segera-kadalurwarsa-tanpa-kepastian-akan-adapenggantinya/1552087.html Diakses pada 5 Juli 2020 
IESR, Indonesia dan Ratifikasi Paris Agreement: Di Manakah Kita?. http://iesr.or.id/indonesia-dan-ratifikasi-parisagreement-di-manakah-kita/ Diakses pada 5 Juli 2020

Kompas. Memahami Isi Dari Kopenhagen. https://internasional.kompas.com/read/2010/02/01/ 03250389/Memahami.Hasil.dari.Kopenhagen?page=all . Diakses pada 5 Juli 2020

Time. Japan Is Spending $\$ 107$ Million to Rebuild a Tiny Pacific Island. https://time.com/4205570/okinotorishimajapan-maritime-claims/ Diakses pada 20 Agustus 2020 